\title{
As práticas no extrativismo vegetal no rio Negro: políticas exíguas, imobilização da força de trabalho de povos indígenas e seu enfrentamento
}

Forest extractivism in Rio Negro: weak policies, indigenous peoples' indented labor and its confrontation

\author{
Elieyd Sousa de Menezes* \\ *Universidade Federal do Maranhão - São Luís, MA, Brasil \\ elieyd@gmail.com \\ https://orcid.org/0000-0002-2473-5621
}




\title{
Resumo
}

Este artigo se propõe a refletir sobre os diferentes processos sociais referentes ao extrativismo vegetal no rio Negro, Amazonas, no que tange à relação entre povos indígenas, atos de Estado e comerciantes conhecidos como "patrões". Esses processos são marcados por dominação, poder e resistência. A partir do trabalho de campo, realizado de 2007 a 2017 em Barcelos (AM) e o levantamento bibliográfico e documental, pude averiguar narrativas de expedições científicas de viajantes naturalistas, de administradores coloniais, de intervenções estatais através de políticas desenvolvimentistas e, até mesmo, processos organizativos de movimentos sociais. A imobilização da força de trabalho de povos indígenas vem sendo praticada nas relações extrativistas desde as assim chamadas "drogas do sertão". Atualmente essa prática é norteada pela dívida no âmbito do "sistema de aviamento". Apesar dessa imobilização, os povos indígenas historicamente vêm encontrando maneiras de enfrentar tais situações, seja pela fuga, pelo não pagamento de uma dívida forjada e, mais recentemente, judicializando suas reivindicações.

Palavras-chave: extrativismo; dívida; enfrentamento; povos indígenas.

\begin{abstract}
This article analyzes forest extractivism in Rio Negro, Amazonas, based on ethnographic fieldwork in Barcelos (2007-2017), document analysis and a bibliographical review. I investigate the narratives of naturalist scientific expeditions, colonial administrators, developmentalist state policies, and indigenous social movements. I focus on the historical relations of domination and resistance between indigenous peoples, the state and merchant 'patrons.' The state and merchant patrons have coerced indigenous peoples since the colonial "drogas do sertão" herb extractivism. Currently, merchant patrons keep indigenous laborers in debt-bondage under the "aviamento" system. Indigenous peoples have confronted labor indenture by fleeing, defaulting on forged debt, and, currently, judicializing their claims.
\end{abstract}

Keywords: extractivism; debt bondage; confrontation; indigenous peoples. 
A atividade do extrativismo, coleta, caça e pesca na Amazônia brasileira tem se desenvolvido, historicamente, sob o viés da patronagem. Dentre outras situações empiricamente observáveis, posso citar os casos da seringa, da piaçaba, da pesca comercial e ornamental, nos quais se têm registros no rio Negro dessa relação.

Essa atividade econômica foi explicada, tanto pelos chamados intérpretes da Amazônia quanto por atos de Estado, como suplementar em relação à agricultura em larga escala, como destrutiva dos recursos naturais, de isolar famílias e pressupor o nomadismo (Superintendência do Plano de Valorização Econômica da Amazônia, 1954). Com exceção da seringa, que após a sua decadência econômica, em um determinado momento histórico, voltou a estar nesse plano periférico. Tal fato acabou colaborando para o fortalecimento da patronagem na região, reproduzindo, assim, a imobilização da força de trabalho de povos indígenas, tal como no período colonial.

O objetivo, neste artigo, é é refletir sobre os diversos processos sociais referentes ao extrativismo vegetal no rio Negro, Amazonas, no que tange à relação entre povos indígenas, atos de Estado e comerciantes conhecidos como "patrões".

Durante o trabalho de campo no município de Barcelos, médio rio Negro, Amazonas, entre os anos de 2007 e 2017, pude acompanhar o piaçabeiros, que assim se autodefinem por serem trabalhadores extrativistas das fibras de piaçaba e que, também, acionam suas identidades étnicas, como baré, tukano, dessano, baniwa. Os piaçabeiros trabalham para os patrões, no âmbito do sistema de aviamento. Há mais de um século esse sistema é conhecido na região e funciona através do adiantamento de mercadorias e dinheiro do patrão ao trabalhador extrativista, instaurando uma dívida.

A partir da reflexão sobre o extrativismo da piaçaba, comecei a investigar como esta atividade era interpretada e tratada não só entre os agentes sociais referidos nessa relação, mas também em esquemas interpretativos e atos de Estado.

É oportuno verificar que desde o período colonial até os dias de hoje, no âmbito do sistema de aviamento, há a utilização da força de trabalho de povos indígenas nas atividades extrativistas, que em distintas situações enfrentaram

1 Agradeço aos amigos Gabriel Locke e Camila do Valle pela leitura e sugestão no texto e abstract. 
do modo que conseguiram. Se no período colonial havia as fugas, hoje ocorre a judicialização das suas reivindicações.

\section{Políticas governamentais na Amazônia para o extrativismo vegetal}

Dentre os vários processos relacionados ao extrativismo na Amazônia, e em especial os que perpassam o rio Negro, cito a procura das chamadas "drogas do sertão", ${ }^{2}$ o extrativismo da borracha em larga escala no século XIX e meados do XX e, após sua decadência, a construção de Planos de desenvolvimento para a Amazônia, também no século XX.

Durante o período colonial, a economia foi marcada por políticas de exploração dos recursos naturais e da força de trabalho compulsório de povos indígenas. Até meados do século XVIII, a extração e coleta das "drogas do sertão" foram coordenadas pelas missões religiosas, tais como jesuítas e carmelitas.

Cardoso e Müller (1978) apontam que o povoamento colonial na Amazônia ocorreu durante os séculos XVII e XVIII, quando os portugueses saíam de Recife e Salvador para expulsar os ingleses, holandeses e franceses que se apoderaram das "drogas do sertão" na região. A partir daí, surgem alguns núcleos considerados importantes estrategicamente, que depois se tornaram as cidades de São Luís, Belém, Macapá e Manaus. Nesses núcleos se reuniam aldeamentos indígenas e "colonos" que objetivavam a coleta dessas "drogas" e que, posteriormente, tentariam o seu cultivo, como uma estratégia de se apossarem efetivamente dessas áreas.

É possível verificar que desde o período colonial, com as "drogas do sertão", o projeto de uma economia extrativista para uma economia agrícola já era pensado, talvez porque esta segunda pressupunha a permanência do homem na terra em comparação à primeira.

2 Conforme Meira (1993), no período colonial as "drogas do sertão" eram os produtos extraídos da fauna e flora para fins múltiplos e tinham mercado tanto na própria colônia quanto nos países europeus. No período colonial, destacavam-se como "drogas do sertão": óleos vegetais, plantas aromáticas, fibras, gomas elásticas em geral, canela, guaraná, gengibre, tabaco, breu, pimentas, dentre outros. 
Com o Diretório Pombalino, em 1755 as missões jesuítas foram retiradas, passando à administração colonial o monopólio da atividade extrativista das "drogas do sertão". Nesse ano, foi criada a Companhia de Comércio do Estado do Grão-Pará e Maranhão, que visava o incentivo da agricultura em larga escala de algodão, cacau e cana, por exemplo. A extração das "drogas do sertão" ficou num plano secundário nas políticas de intervenção econômica em relação à agricultura em larga escala. As duas explorações continuaram sendo cultivadas através da força de trabalho compulsória.

Autores como Benchimol (1966) e Reis (1944) afirmam que o projeto da implantação de uma economia agrícola (para exportação) não deu certo até o início do século XIX, por falta de "mão de obra" ou desvio da produção para os territórios espanhóis. A "mão de obra" referida nesse argumento se trata da força de trabalho, ou, mais explicitamente, trabalho escravo. Quanto mais trabalhadores imobilizados nas plantações de larga escala, maior a produção agrícola nesse período.

Almeida (2008) aponta que a ideologia oficial do chamado "progresso" é lida por comentadores regionais enquanto um período da "idade de ouro" no Maranhão e Pará, por exemplo. Este "progresso" é todo construído a partir de empreendimentos algodoeiros e canavieiros com a introdução da força de trabalho escrava das costas da África. Aliado a isso, tem-se a utilização do conhecimento técnico de arquitetos, agrônomos, bacharéis em direito e médicos que "reproduziam essa sociologia espontânea de explicação da Amazônia" (Almeida, 2008, p. 25).

Ao estudar o "Amazonas na época imperial", Loureiro (2007) aponta o extrativismo como uma atividade importante; ainda assim, só consta nos registros contábeis na época como significante a partir da produção da borracha. Segundo esse autor o extrativismo era a principal ocupação dos povos indígenas que habitavam o Amazonas durante a época imperial, tanto o de origem vegetal quanto animal. Isso até a borracha predominar nas exportações.

Segundo Loureiro (2007, p. 230), “todos os anos, na vazante, a população ia para as praias e florestas, abandonando as demais ocupações para dedicar-se ao extrativismo". Desse modo, essas atividades extrativistas compreendiam as pescarias e a salga do pirarucu, o fabrico da manteiga de tartaruga e da gordura de peixe-boi e das mixiras, a extração do óleo de copaíba, a colheita do breu, do cacau, da castanha, da piaçaba, do cravo, da estopa, da salsaparrilha, 
do cumaru e do puxuri, o preparo do couro de animais silvestres e o beneficiamento da madeira, além da produção de goma elástica.

Com o advento da Revolução Industrial na Europa, a demanda pela borracha começou a se tornar algo expressiva; sendo procurado e valorizado, esse produto extrativista entrou num cenário internacional, alterando as receitas do Estado. Apesar da dinâmica proporcionada por esse momento, como projetos de estradas, "modernização" de capitais e a visibilidade internacional, essa economia continuou sendo baseada na imobilização da força de trabalho, na violência e na dívida.

Benchimol (1966) avalia positivamente que a "Amazônia interior" encontrou a oportunidade de desenvolvimento com a borracha. Isso porque com a invenção do pneu e da indústria de veículos, os preços desse recurso natural subiram e se pôde avaliar o papel dessa matéria-prima para a economia na Amazônia e para o desenvolvimento da indústria mundial.

As instituições bancárias estatais, inclusive, só vêm para a Amazônia no período de grande exportação gomífera, tal como aponta Reis (1958). Antes disso, o autor menciona que, com a ausência do banco formal, a economia se desenvolvera sob a égide do sistema do aviamento.

Segundo Reis (1958), na Amazônia, as relações de troca foram processadas na base de um aparelhamento que foi constituído pela rede de "casas aviadoras", que exerceram por muito tempo o papel que devia caber às organizações bancárias. As "casas aviadoras" se constituíam enquanto empresas que enviavam mercadorias às unidades de produção (seringal, castanhal, piaçabal) em troca do pagamento em produtos extrativistas.

A situação da imobilização da força de trabalho por empresas seringalistas já era percebida, como aponta Almeida (2008), tanto em atos imperiais quanto em atos republicanos. Por exemplo, nos atos imperiais de 1877, na implementação do Plano de Defesa da Borracha em 1912, e no Acordo de Washington firmado em 1942, é possível verificar o incentivo do deslocamento da força de trabalho nordestina para a Amazônia, que "redefiniu o sistema extrativista na região amazônica, impondo os rigores de uma 'economia de guerra" (Almeida, 2008, p. 26-27, rodapé).

Apesar da borracha extraída no rio Negro ser considerada inferior e ter um preço abaixo das que eram extraídas em outros rios na Amazônia, nos anos da intensa comercialização desse produto havia profunda mobilização em torno dos seringais nesse rio, imobilizando a força de trabalho dos povos indígenas. 
No processo de declínio da demanda por esse produto extrativista, seja porque a Amazônia perdeu o monopólio quando os seringais nas colônias inglesas da Ásia começaram a ser produtivos no século XX, já que suas sementes foram biopirateadas ainda no século XIX, seja pela inserção da borracha sintética no mercado, começaram, então, a ser discutidos mais diretamente os planos de valorização para a Amazônia.

Com a Constituição de 1946 foi criado o Plano de Valorização da Amazônia. No entanto, sua implementação ocorreu em 1953 com a criação da lei ${ }^{\circ} 1.806$ (Brasil, 1953), que instituía o Plano de Valorização Econômica da Amazônia e criava a Superintendência do Plano de Valorização Econômica da Amazônia (SPVEA). Subordinada diretamente à Presidência da República, a SPVEA tinha como objetivo assegurar a ocupação da Amazônia no Estado brasileiro e constituí-la em uma sociedade economicamente estável e progressista, através do fomento da atividade agrícola e pecuária.

O extrativismo vegetal, com exceção da indústria gomífera, é apresentado no $1^{\circ}$ Plano Quinquenal dessa superintendência como uma economia que dispersa as pessoas na floresta, o que não seria estrategicamente oportuno ao Estado, que objetivava o oposto para marcar uma presença nesse território.

Considerado, portanto, como um obstáculo ao desenvolvimento da região amazônica, o extrativismo vegetal aparece no Plano Quinquenal como algo que deve ser transformado gradualmente. A conversão da economia extrativa em agrícola (em larga escala) seria um dos objetivos, a começar pela criação de núcleos agrícolas de colonização que concentrariam a população, caso contrário, haveria a dispersão e o extrativismo seria novamente a atividade econômica principal, o que não levaria ao desenvolvimento, de acordo com os ideais estatais.

Em 1966, na ditadura militar, o SPVEA foi substituído pela Superintendência do Desenvolvimento da Amazônia (Sudam), criada com o intuito do planejamento, coordenação, promoção, execução e controle da ação federal na Amazônia Legal, ${ }^{3}$ tendo em vista o desenvolvimento regional.

3 Junto com a criação da SPVEA, através da lei $\mathrm{n}^{\circ}$ 1.806, de 6 de janeiro de 1953, o conceito de Amazônia Legal foi instituído para efeitos de planejamento econômico. Os limites da Amazônia Legal ultrapassam a área do bioma amazônico, sendo, portanto, um conceito político. Fazem parte da Amazônia Legal os seguintes estados: Amazonas, Pará, Acre, Amapá, Mato Grosso, Rondônia, Roraima, Tocantins e parte do Maranhão. 
A partir de 2013, em outro momento político, começa a ser discutido o Plano Nacional de Fortalecimento do Extrativismo, coordenado pelo Ministério do Meio Ambiente (MMA). Com a portaria interministerial $\mathrm{n}^{\circ} 380$ (Brasil, 2015), de 11 de dezembro de 2015, foi instituído o Plano Nacional para o Fortalecimento das Comunidades Extrativistas e Ribeirinhas (Planafe), que objetiva a promoção da inclusão social da produção sustentável, da melhoria da infraestrutura e do apoio à gestão ambiental e territorial dos povos e comunidades tradicionais.

Dentro dessa política, é acionada a Companhia Nacional de Abastecimento (Conab), que é vinculada ao Ministério da Agricultura, Pecuária e Abastecimento (Mapa). A Conab tem como responsabilidade garantir, por meio de programas de apoio, rendimentos ao produtor rural. Nesse contexto, tem-se o Plano de Aquisição de Alimentos (PAA) e a Política de Garantia de Preços Mínimos dos Produtos da Sociobiodiversidade (PGPM-Bio). O PAA trata-se de uma política que objetiva a promoção do acesso a alimentos às populações consideradas em estado de insegurança alimentar. A PGPM-Bio objetiva proporcionar, por meio de subvenção, que o trabalhador extrativista receba um apoio financeiro ao comprovar que efetuou a venda de seu produto por preço inferior ao mínimo fixado pelo governo federal.

Na ocasião do trabalho de campo em Barcelos no ano de 2017, pude acompanhar o processo do pedido da subvenção de piaçaba, junto aos piaçabeiros e ao órgão responsável no município por essa atividade, o Instituto de Desenvolvimento Agropecuário e Florestal Sustentável do estado do Amazonas (Idam).

Se compararmos os incentivos e políticas públicas construídas até então, é possível verificar que a assistência específica às atividades extrativistas é recente e exígua. Todavia, ainda vigora a ideia de que tais atividades dispersam os povos, fomentam o "nomadismo" e não promovem o desenvolvimento. Persistem também as interpretações sobre povos e comunidades tradicionais que vivem do extrativismo (dentre outras atividades) de que estes estão situados numa perspectiva de continuação da natureza, numa ótica "primitiva".

Com a mobilização de movimentos sociais acionando identidades coletivas através de um critério de ocupação, tais como seringueiros, castanheiros, piaçabeiros, concomitantes ou não às identidades étnicas, como tukano, dessano, baré, essas visões pejorativas construídas, desde o período colonial, podem estar começando a ser minimizadas. Isso proporciona a tomada de espaços 
para reivindicações, chamando atenção para o tema nas pautas das políticas públicas para a região.

\section{A economia agrícola e extrativista no rio Negro lida nos relatos de viajantes naturalistas, expedições científicas, colonialistas/imperialistas e missionárias}

Os relatos privilegiados, aqui, referem-se tanto àqueles de viajantes naturalistas, como Alexandre Rodrigues Ferreira, que percorreu este rio em 1783, Spix e Martius em 1820, Alfred Russel Wallace em 1853, quanto às narrativas de expedições científicas, colonialistas/imperialistas e missionárias, como as de Gonçalves Dias em 1862, Theodor Koch-Grünberg entre 1903 e 1905, o bispo Frederico Costa em 1909, Robert Avé-Lallemant em 1859 e Santa-Anna Nery entre 1884 e 1885.

Nas datas das expedições de Alexandre Rodrigues Ferreira, Spix e Martius tratava-se de um Brasil colonial, enquanto nas de Alfred Wallace, Robert Avé-Lallemant, Santa-Anna Nery e Gonçalves Dias, de um Brasil imperial. Já na viagem de Frederico Costa e Theodor Koch-Grünberg se tratava de um Brasil republicano, sendo a de Costa uma viagem missionária. Essa distinção se faz necessária para a compreensão dos sentidos das descrições que estavam voltados aos interesses relacionados aos momentos políticos da época, discursos científicos e esquemas interpretativos diferentes.

O intuito de ler os relatos desses viajantes é verificar como o extrativismo nesse rio era descrito em relação aos povos que praticavam essa atividade. Pacheco de Oliveira (1987) afirma que havia um conjunto normatizador para as viagens que não era aleatório, ou seja, havia regras para o que olhar, por que olhar e como olhar, pois o Estado precisava usufruir das informações que os viajantes traziam.

Alexandre Rodrigues Ferreira, ${ }^{4}$ entre os anos de 1783 e 1792, foi encarregado de realizar uma viagem às capitanias do Grão-Pará, Rio Negro, Mato Grosso e Cuiabá com o intuito de corresponder a uma determinação da rainha D. Maria I,

4 Doravante Ferreira. 
que ordenou uma viagem exploratória ao centro-norte da colônia com objetivos de visualizar novos potenciais econômicos.

Jobim (1965) revela que ao ler Ferreira na Revista do Instituto Histórico e Geográfico Brasileiro (IHGB) de 1885, ficou admirado com o esforço do governo português de atribuir ao rio Negro uma ideia de eficiência na agricultura, indústria e comércio.

Ao buscar a referência citada por Jobim (1965), ou seja, a revista do IHGB de 1885 , encontrei no diário da viagem filosófica dados referentes à economia nesse rio. Ferreira (2007) descreve as culturas de mandioca (e seus produtos derivados, como beiju, tucupi, farinha, polvilho, tapioca), café, arroz, cacau, algodão, cana-de-açúcar, tabaco, feijão, anil, piaçaba, borracha, sorva, cipós, além de legumes, ervas, plantas aromáticas e medicinais, frutas e outros produtos como artesanatos, cerâmicas e aqueles de origem animal, como manteiga de tartaruga, azeite de peixe-boi e pirarucu seco, em algumas localidades desse rio, como: Barcelos, Moreira, Moura, Thomar, Lamalonga, Uaupés, São Gabriel da Cachoeira, dentre outros. Este viajante naturalista indica para exportação o seguinte: breu, salsa, cacau, puxiri, puxuri-mirim (ou fruto da árvore da casca preciosa), bálsamo de umiri, piaçaba, muirapiranga e pau-roxo e pau-amarelo.

Vale ressaltar que Ferreira (2007) descreveu em seu diário que no ano de 1786 não havia gente para mandar coletar as "drogas do sertão", e mesmo se houvesse, seria mais lucrativo empregá-los na agricultura.

Carvalho Júnior (2011) observa que Ferreira descreveu os povos indígenas da Amazônia como trabalhadores explorados, tanto no Diretório Pombalino quanto no Regimento das Missões. Pondera, sobretudo, que o viajante naturalista considerava essa exploração como benéfica, pois tornaria os povos indígenas necessários e úteis.

Sendo assim, os povos indígenas na Amazônia, para Ferreira, eram associados ao grupo dos mamíferos da taxonomia de Lineu, ${ }^{5}$ enquadrando-os em um grau menor de humanidade, atrelado aos parâmetros das ciências naturais muito fortes na época. Eram sujeitos, sobretudo, biológicos, ligados ao reino da natureza. Dentre as etnias citadas, estão: "Manaus, Barés, Carajaís, Japiúas, Baniuas, Jaruna” (Ferreira, 2007, p. 36), “Uajuanás, Guirinas, Passés” (Ferreira,

5 A taxonomia de Lineu dispõe as coisas vivas em uma hierarquia, começando com os reinos, que são divididos em três: mineral, animal e vegetal. E, dentro de cada reino, há subdivisões. 
2007, p. 50), “Carajaí, Uarinas” (Ferreira, 2007, p. 43), “Uaupés, Juris, Uerequenas, Baniuas, Maquiritare e Macu” (Ferreira, 2007, p. 70).

No século XIX, especificamente de 1817 a 1821, ou seja, quase três décadas depois da viagem de Alexandre Rodrigues, uma missão austro-alemã é destacada ao Brasil e nela vêm Johann Baptist Ritter von Spix e Carl Friedrich Philipp von Martius, dois naturalistas da Baviera.

No percurso do rio Negro, segundo Spix, antes da década de 1820, contavam-se mais de 50 etnias diferentes, dentre elas: manao, aroaqui, baré, baniwa, passé, juri, coretu, macuná, iupuá, coeruna, uainumá, cauari, marauá, jumana, catauixi, amamati, miranha, tarumã, uaranacoacena, carais, juma, parauana e maranacuacena, baianai, uariquena.

Spix descreve que no rio Negro eram mantidas olarias e salas de fiação a partir do emprego do trabalho de indígenas, e eles eram pagos com valores ínfimos, incertos e precários; porém, é em notas de rodapé que Spix se debruça sobre a ideia da perfectibilidade ${ }^{6}$ como respaldo da utilização da mão de obra escrava indígena. Quando Spix percorreu esse rio, os produtos que prevaleciam na agricultura eram a mandioca, o café e o anil.

Nos anos de 1848 a 1852, Alfred Russel Wallace, naturalista inglês, ao percorrer o rio Negro tinha como objetivo coletar insetos e outras espécies animais para vendê-los a colecionadores na Inglaterra, sobretudo a museus de história natural. Ele veio ao Brasil juntamente com o entomologista Henry Bates, e mantinha um diálogo através de cartas com Charles Darwin.?

Wallace (1953) afirmou que uma grande parte da população do alto rio Negro corta e colhe as fibras da piaçaba para exportação, sendo localizadas nos rios Padauari, Jaá e Daraá, na margem setentrional do rio Negro, e as dos rios Marié

6 O ideal da perfectibilidade resultava no que Martius chamava de "racismo da ilustração", ou seja, o homem europeu estava mais próximo desse ideal, designado por ele como uma relação entre a beleza física e o caráter moral. Sobre esse assunto, Martius pensa que, quando falta a perfeição física para o europeu, ele compensa com a existência do caráter moral. Enquanto isso, o mais próximo que os povos indígenas chegavam do ideal de perfectibilidade era na categoria de "semicivilizados", e os que permanecessem "sem deus, sem rei e sem lei" desapareceriam. A ideia da perfectibilidade respaldava a utilização da mão de obra escrava de indígenas e negros na Amazônia.

7 Wallace tornou-se, posteriormente, um dos correspondentes de Darwin em viagens à Malásia e Indonésia, e seus textos contribuíram com Darwin, que os utilizou para dar suporte às suas teorias. 
e Xié, na margem meridional. Desse modo, foi descrita como moeda de troca, já que seu valor comercial era um dos mais altos em relações a outros produtos.

$\mathrm{O}$ percurso desse trabalho com a piaçaba aparece no referido relato como árduo e demorado, tendo os indígenas que percorrerem duas viagens de dez milhas ${ }^{8}$ para transportar as fibras cortadas.

Uma década depois da viagem de Wallace, em 1859, o médico alemão Robert Avé-Lallemant publicou as descrições das suas viagens ao norte do Brasil. Esse viajante, que além de médico é conhecido como explorador, veio ao Brasil, a convite de Alexander von Humboldt, como membro da expedição austríaca Novara, que foi organizada pela Academia Imperial de Ciências em Viena e objetivava recolher artefatos botânicos, zoológicos e etnográficos aos museus austríacos. Ele resolveu ficar no Brasil mais tempo que a expedição e percorreu o norte e nordeste brasileiro sozinho, apoiado por D. Pedro II. ${ }^{9}$

Das atividades econômicas dos povos indígenas no rio Negro, Avé-Lallemant descreve sobre a pesca e agricultura familiar dos barés, "aeroquenas" e "banibas". As mulheres teciam redes de tucum e caroá para vender aos ambulantes, segundo o autor, "por uma ninharia" (Avé-Lallemant, 1980, p. 116). Desse modo, além da agricultura e extrativismo, é possível ler no relato desse viajante um comércio com os chamados "regatões" - comerciantes ambulantes que percorrem os rios trocando mercadorias.

Avé-Lallemant conseguiu obter com o então gerente da Companhia de Navegação e Comércio do Amazonas, o sr. João José de Freitas Guimarães, dados relativos aos produtos transportados em 1858, como seringa, cacau, piaçaba, tabaco, guaraná, castanhas, salsaparrilha, café e madeiras. Pude encontrar dados semelhantes no acervo da firma comercial J. G. Araújo, localizado no Museu Amazônico (Ufam) em Manaus.

Já em 1861-1862 Antônio Gonçalves Dias percorreu os rios Negro e Solimões a convite do Instituto Histórico e Geográfico Brasileiro (IHGB) no âmbito da expedição da Comissão Científica de Exploração, organizada e financiada pelo, então, imperador D. Pedro II.

8 Aproximadamente $16,09 \mathrm{~km}$.

9 Dados biográficos de Robert Avé-Lallemant foram levantados no acervo digital da Deutsche Nationalbibliothek (DNB) [Biblioteca Nacional da Alemanha]. 
As narrativas de Dias (1964) apontam que no rio Negro a economia era baseada no extrativismo de subsistência dos povos indígenas, seja vegetal ou animal. E que o tempo empregado no extrativismo diminuía as possibilidades de prosperidade através da agricultura, sendo esta propícia para o cultivo de algodão, café e anil.

Esse argumento de que a prosperidade vem com a agricultura também é visto no trabalho de Santa-Anna Nery (1979). Esse autor não está procurando descrever microeconomias no Amazonas, como as dos povos indígenas, e, sim, as macroeconomias através dos índices de exportação do Estado (final do Império). Ele separa os potenciais econômicos de acordo com as classificações taxonômicas de Lineu. Uma preocupação desse autor é que a indústria gomífera no Amazonas estava em um momento que ele chamou de exclusivismo econômico, e isso era preocupante, já que todas as demais atividades extrativistas e agrícolas estavam sendo diminuídas pela atividade principal da seringa.

É oportuno ressaltar que enquanto o rio Purus exportava $3.459,455 \mathrm{~kg}$ de seringa, o rio Negro exportava $221.930 \mathrm{~kg}$, de acordo com o levantamento feito por Santa-Anna Nery em 1882-1883. A exportação deste segundo rio não era tão significativa aos cofres do Estado, mas era suficiente para estabelecer relações de trabalho e comerciais que supunham dominação e poder.

No rio Uaupés, no ano de 1903 chega o etnólogo alemão Theodor Koch-Grünberg. Ele foi encarregado pela direção do Real Museu da Etnologia, em Berlim, para realizar uma viagem na região do rio Amazonas para montar uma coleção de objetos etnográficos.

As etnias que Koch-Grünberg foi conhecendo e citando ao longo do rio Negro foram: tariano, uanána, korekaru, baré, uarekena, arapaso, siusí, tukano, dessano, makus, baniwa, karutana, piratapuyo, bará e kobéua (Koch-Grünberg, 2005). As atividades econômicas desses povos são descritas, com certas variações, a partir da caça, pesca e extrativismo; este último, exercido através do uso compulsório da força de trabalho nos seringais por comerciantes.

Koch-Grünberg estava no rio Negro no momento de alta da indústria gomífera, e observou que as atividades nos seringais eram intensas. Ao longo de sua viagem conheceu comerciantes, regatões e representantes de firmas comerciais, e destacou que a relação desses comerciantes com os povos indígenas era marcada por violência através da repressão da força de trabalho, sobretudo nos 
seringais, piaçabais e em alguns povoados onde comerciantes residem. Relatos como esses são vistos também nas descrições do bispo Frederico Costa, em 1909, ocasião em que empreendeu uma viagem pastoral para realizar missas e batizados entre os povos indígenas que habitavam o rio Negro.

Em alguns povoados ao longo do rio, referidos aos indígenas barés e hupdas, a pesca, a agricultura e o extrativismo são evidenciados como atividades econômicas desses povos. Atos de tecer (redes e cordas), extrair piaçabas, puxuri, salsa, breu e óleos são realizados e elencados como elementos econômicos também. Costa termina sua carta pastoral, dentre outros argumentos, afirmando que "achamos, pois, que chegou o momento de protestar contra o abandono em que se acha o rio Negro, sob pretexto de que suas terras nada produzem. É falso" (Costa, 1909, p. 107).

O bispo descreve que "o nosso índio é trabalhador e, sobretudo a índia, raríssimas vezes vimos as mulheres paradas [...]. Plantam mandioca, cana, annanáz, banana, a pupunheira, bacaba e toda a sorte de fruteiras" (Costa, 1909, p. 58).

O religioso observa, ainda, que muitos trabalhadores extrativistas, indígenas, sobretudo, são usados em relações comerciais de forma compulsória, com sua força de trabalho. O discurso é que o trabalho os tornaria mais "civilizados". Dentre os relatos dos viajantes mencionados, a dívida vai aparecer como algo que imobiliza os povos indígenas, atrelada à repressão da força de trabalho e às violências físicas, como é possível ver a seguir.

\section{Sobre o sistema de aviamento no rio Negro, a imobilização da força de trabalho e a servidão por dívida}

A imobilização da força de trabalho no extrativismo pode ser reforçada com a ideia de que tal atividade econômica é considerada como algo que dispersa, que não cria unidade, que não é viável economicamente para o Estado, como apontado no início deste artigo.

Esse discurso está elencado com modelos analíticos de ciclo econômico arraigados nos esquemas interpretativos sobre o extrativismo na Amazônia que o colocam sempre numa posição de decadência econômica e de idealização do passado. Esses modelos analíticos, cujas leituras afirmam a decadência do extrativismo na Amazônia, estão referidos aos pressupostos evolucionistas 
marcados pelo continuum linear. Desse modo, os processos evoluem e passam a ser resíduo ou sobrevivência de uma atividade cultural e econômica.

Numa crítica a essa ideia, aproprio-me das análises feitas por Pacheco de Oliveira (1979) sobre a noção de ciclo enquanto modelo analítico que a partir de generalidades, unidades e tipicidade de interpretação omite alguns temas oportunos para a compreensão dessa situação social, como a força de trabalho indígena ou o desenvolvimento de outros tipos de produção.

A partir dos relatos vistos acima, é possível notar que as descrições referentes aos povos indígenas no rio Negro e sua economia eram baseadas na observação da agricultura familiar e no extrativismo em pequena escala, mesmo durante o auge da indústria gomífera na região.

O extrativismo de subsistência é tratado nas políticas do Estado, sobretudo até o século $\mathrm{XX}$, como uma economia inferior em relação à agricultura. $\mathrm{E}$ a imobilização da força de trabalho dos povos indígenas da região é vista nos discursos, sobretudo de Ferreira (2007), Spix e Martius (1981), Costa (1909) e Santa-Anna Nery (1979), como algo que deveria ser empregado não só no extrativismo, mas também na agricultura e no que mais fosse necessário para elevar as riquezas da região.

Essa relação remonta ao período colonial, quando os povos indígenas foram escravizados através de políticas como as tropas de resgates ou os descimentos. Ou seja, podiam ser tomados como força de trabalho escravo aqueles indígenas que praticavam antropofagia, não fossem cristãos, fossem aliados dos inimigos de Portugal, e até resistentes à catequização. Vale ressaltar que as missões religiosas, antes de Pombal, eram responsáveis por "administrar" os indígenas.

Chambouleyron e Bombardi (2011) afirmam que não somente o Estado colonial e as missões religiosas faziam uso da força de trabalho compulsória dos indígenas. Havia também alvarás de descimentos a particulares, ou seja, licenças que pessoas solicitavam ao Estado para escravizar os indígenas em suas roças, comércios, e onde mais se necessitasse de força de trabalho.

Nimuendajú (2001) entre 1929-1932 também já tinha observado que os indígenas eram depreciados seja através da catequização cristã ou do trabalho compulsório pelos seringalistas, justificativas de um projeto de colonização violento. A imobilização da força de trabalho dos povos indígenas, dentre outros fatores, encontrou força em sua reprodução através da servidão pela dívida, que foi sendo construída por um sistema de aviamento. 
Teixeira (2009) observa que o processo comercial do aviamento possui dois momentos distintos: o primeiro diz respeito ao aviamento como uma organização comercial destinada à exploração dos recursos naturais, assumindo um caráter mercantil. Já o segundo reveste-se da forma do barracão, ${ }^{10} \mathrm{e}$ as relações sociais ganham um novo conteúdo, diferente do caráter mercantil, em que são marcadas pela coerção e não pelo mercado.

Euclides da Cunha (2003) abordou os mecanismos de endividamento nessa relação patrão (comerciante) e freguês (trabalhador extrativista). $\mathrm{O}$ autor narra que o freguês trabalha para escravizar-se, já que as dívidas que prendem o trabalhador ao patrão dificilmente são pagas. Esse sistema econômico é narrado por Euclides da Cunha como um sistema escravo que funciona através do endividamento.

Nesse caso, o trabalhador extrativista fica dependente do comerciante no que se refere ao transporte, já que as distâncias percorridas entre os locais de potenciais extrativistas (situados nas florestas) e os povoados ou cidade são grandes, e somente os comerciantes detêm barcos e combustível para a realização dessas viagens. É imposta a esse trabalhador uma série de dívidas referentes não só ao transporte, mas também aos meios de produção e alimentação a preços mais altos que no mercado. Assim, ele fica numa dívida que dificilmente pagará, pois o objetivo do comerciante é manter essa força de trabalho sempre devendo para que fique imobilizada e não consiga transitar entre outras relações comerciais.

Costa (1909) afirmou que alguns comerciantes chegavam nas aldeias armados com rifles, ameaçavam e exigiam o que queriam, obrigando os homens a trabalharem para eles, estuprando as mulheres, embriagando os idosos e espancando quem resistia.

Koch-Grünberg (2005, p. 624) também comenta a situação de imobilização da força de trabalho, e as violências que os povos indígenas sofriam, afirmando que "o sopro pestilento de uma pseudo-civilização anda por sobre os povos morenos, que não possuem direitos [...]. Atos de violência bruta estão na ordem do dia."

10 O barracão assume diferentes significados dependendo da unidade de produção. No seringal, referia-se ao local de comercialização e pesagem dos produtos extrativistas; no piaçabal, ao local de moradia dos trabalhadores enquanto estavam na floresta exercendo suas atividades de trabalho. 
Esse etnólogo cita situações que observou entre 1903 e 1905 nas quais a violência não era o único meio de conseguir a força de trabalho dos indígenas na região. Era possível também manter relações ditas amigáveis, atraindo, portanto, essa força de trabalho.

Nessas relações comerciais há situações em que o trabalhador extrativista, por estar imobilizado pela dívida, cumpre seu trabalho com exclusividade para o comerciante ao qual está devendo e somente este pode liberá-lo para outra atividade. As cadeias comerciais extrativistas nos rios amazônicos, que tinham como principal força de trabalho os povos indígenas, estavam apoiadas nesse sistema de aviamento.

Tem-se de um lado, um comerciante que possui os meios de produção e os demais recursos necessários para se obter um produto extrativista como castanha, seringa, piaçaba, madeira. Por outro lado, há um trabalhador extrativista que tem os conhecimentos e práticas necessários para ir à floresta e extrair os recursos naturais, mas não tem os meios de produção, somente sua força de trabalho. Esses agentes sociais também se autodefinem hoje, a partir da atividade que ocupam e se identificam, como "castanheiro", "seringueiro", "piaçabeiro".

O comerciante, então, tendo interesse em algum produto extrativista, troca mercadorias industrializadas e dinheiro pela força de trabalho dos trabalhadores extrativistas. Acontece que quem impõe os preços dos produtos trocados é o comerciante, evidenciando um aspecto de dominação em uma relação comercial e sua unilateralidade.

Durante o trabalho de campo em 2017, ocorrido em Barcelos, perguntei a vários agentes sociais, dentre patrões e piaçabeiros, sobre o sistema de aviamento, e encontrei as seguintes respostas conforme seus pontos de vista:

O aviamento, eu vejo assim, eu acho que é um crédito, a senhora não tem um cartão de crédito? $\mathrm{O}$ aviamento para nós é isso, o cara quer comprar um rabeta, ele não pode comprar, que ele não tem o capital, o dinheiro, ele não tem crédito aqui no comércio, ele chega comigo, "pô, G., me avia um rabeta?", eu vejo assim, tipo um crédito que o cara tem. (G., comerciante de piaçaba, 2017).

O comerciante das fibras de piaçaba acima me explicou o sistema de aviamento através de uma comparação com um sistema bancário de cartão de crédito. Por 
exemplo, se alguém precisa de dinheiro, procura no banco um empréstimo. Se tiver crédito, consegue. E junto vêm os juros, as taxas e uma dívida parcelada em vários meses. $\mathrm{O}$ banco seria o comerciante, e a pessoa precisando de um empréstimo, o trabalhador extrativista. A diferença é que o trabalhador extrativista não liquida essa dívida em dinheiro, mas, sim, no produto extraído. Essa é a moeda no acordo que fazem.

Um trabalhador extrativista de piaçaba, subordinado ao comerciante acima, explicou-me da seguinte maneira:

Aviamento pra mim é igual um crédito, igual um empréstimo que a gente faz pra pagar no nosso setor de trabalho, igual um empréstimo que a gente pega aqui, que ninguém tem o dinheiro, o capital pra pagar nada, isso aí para mim é o aviamento. Eu pego um bagulho, ele [o patrão] vai me fornecer esse bagulho que eu chamo de aviamento. O bagulho é o meu rancho, a minha cesta básica que eu vou trabalhar pra lá [na floresta], e além da cesta básica, um dinheiro que ele vai me fornecer pra comprar outros materiais que eu necessito pra mim usar lá, isso aí que a gente chama de aviamento do extrativista, é isso. (E., piaçabeiro, 2017).

A palavra "aviamento" vem do verbo "aviar", que tem como sinônimo, dentre outros, "adiantar". Nesse caso, adiantar o dinheiro ou a mercadoria antes do recurso natural ser extraído e beneficiado. O que traz um complexo de relações que envolvem poder, compromisso, honra e dominação. É isso que mantém esse sistema.

Esse sistema no rio Negro foi visto com mais intensidade durante a extração gomífera nos séculos XIX e XX, mas, apesar disso, outros produtos extrativistas até hoje são comercializados a partir dessa lógica, como é o caso da piaçaba, do cipó, da castanha, das madeiras e da própria pesca.

O trabalhador extrativista diz o que e o quanto precisa para trabalhar. O comerciante disponibiliza e a dívida está instaurada. O trabalhador vai à floresta extrair, na volta entrega sua produção ao comerciante para lhe subtrair a dívida. Às vezes ela está tão alta que a produção do trabalhador extrativista não cobre, e este precisa ficar mais tempo na floresta ou voltar depois para continuar o trabalho. Para isso precisa pegar novamente as mercadorias e dinheiro com o comerciante. A dívida aumenta novamente. E o trabalhador continua preso a esse sistema. 
Esse processo é o que Esterci (1996) denomina de peonagem da dívida, que é uma forma de dominação do patrão para com o trabalhador extrativista. A dívida é um elemento da imobilização da força de trabalho. Conforme aponta a autora, "os elementos mais importantes que compõem a peonagem na Amazônia são: a instituição da dívida, naturalmente, a remuneração por produção, a presença dos intermediários e o uso frequente da violência" (Esterci, 1996, p. 130). Então a dívida é um instrumento de dominação de um grupo sobre outro, e mantê-la é fundamental para que o sistema de aviamento continue funcionando.

Costa (1909) aponta que os comerciantes na sua época conseguiam estabelecer a dívida dando mercadorias e iludindo os indígenas, que de boa-fé ficavam presos numa relação comercial imposta. Ao deixar suas terras para trabalhar para os patrões, esses trabalhadores indígenas recebiam apenas uma calça como pagamento.

Koch-Grünberg descreve o que ele denominou de "escravo por endividamento", percebido ao longo do rio Negro. O comerciante fornecia mercadorias fiado e o indígena deveria saldar a dívida com os produtos extraídos na natureza. A dívida nunca seria paga, já que o comerciante sempre "dá um jeito" (Koch-Grünberg, 2005, p. 56-57) para que o trabalhador extrativista não a consiga quitar. E, mesmo que consiga, sempre vai precisar pegar mercadorias fiado novamente. A relação de dependência se estabelece desse modo.

Atualmente em Barcelos, nas relações extrativistas das fibras de piaçaba, no âmbito do sistema de aviamento, um trabalhador pode ficar endividado com dois ou mais comerciantes.

Outra situação observada, tanto no trabalho de campo entre 2007 e 2017 quanto na leitura de viajantes naturalistas pelo rio Negro nos séculos XIX e XX, foi a troca da dívida entre os patrões. Por exemplo, um trabalhador extrativista deve ao "patrão A" e solicita ao "patrão B" que quite a sua dívida com o "patrão A". Desse modo, a dívida é quitada entre os "patrões". E agora o trabalhador extrativista deve somente ao "patrão B", tanto o valor da dívida com o antigo "patrão A" quanto as novas dívidas feitas com o "patrão B", ou seja, a dívida só aumenta.

Koch-Grünberg (2005) narra uma situação no início do século XX com indígenas que extraíam caucho no rio Negro, referida a troca de dívidas entre patrões. O comerciante que quita a dívida aparenta um tom de heroísmo em comparação aos coletores de caucho, o ato de quitar é descrito como uma espécie de "resgate". 
Costa (1909) aponta que um indígena fugiu porque era maltratado e foi à procura de outro patrão. Esse novo patrão lhe recebeu, o aceitou e se comprometeu a quitar sua dívida, mesmo o indígena negando que a tivesse; de qualquer modo, os patrões se acertaram. A dívida é um elemento norteador no sistema de aviamento, porque ela se torna o vínculo, no sentido de prender os agentes sociais referidos nessa relação.

\section{Estratégias de enfrentamento dos piaçabeiros no sistema de aviamento em Barcelos}

Foi possível verificar, até agora, que a força de trabalho compulsória de povos indígenas desde o período colonial constituiu o principal elemento das práticas extrativistas tanto para o Estado quanto para comerciantes. Isso não significa, contudo, que esses povos estivessem exclusivamente em uma posição de subordinação.

Nesse sentido, Reis (1977) apontou que, mesmo com as coerções, os seringueiros vingavam-se com as armas que dispunham, ou seja, negociavam os produtos com terceiros que não faziam parte da relação comercial estabelecida, extraíam látex por processo proibido para acelerar a produção e, assim, aumentar o saldo, ou seja, diminuir a dívida com o seringalista.

Em situações semelhantes aos exemplos acima, a fuga pode ser interpretada também como forma de resistência: Costa (1909, p. 59) afirma que "cansa-se o índio de trabalhar sem ver a recompensa, cansa-se dos maus tratamentos e, um belo dia, foge para o mato".

Já os piaçabeiros em Barcelos acionam outras estratégias para enfrentarem as situações de imobilização da força de trabalho, tais como: não pagarem a dívida, dando o chamado "calote", denunciando às autoridades competentes, participando de unidades de mobilização (Almeida, 2006) como associações indígenas.

O "calote", ou seja, não pagar a dívida, implica a desconstrução de uma imagem de vítima e sujeitos atomizados que esses trabalhadores extrativistas carregam. $O$ ato de não pagar a dívida, todavia, significa também a construção de um estigma de "caloteiro", mau pagador, e tem um efeito social negativo. Manter tal posição é uma prática de resistência nesse sistema de aviamento.

Hoje, nas relações extrativistas das fibras de piaçaba no rio Negro, não pagar as dívidas não implica mais o cerceio da liberdade dos trabalhadores 
extrativistas nos piaçabais como acontecia até a década de 1980. Implica, entretanto, manter o nome "limpo", ou seja, manter uma boa reputação para conseguir o adiantamento das mercadorias com algum comerciante.

Ser um trabalhador honrado e ter compromisso com sua atividade extrativista pressupõe entrar num jogo de poder e dominação com os comerciantes. Nesse sentido, são utilizados no sistema de aviamento princípio morais, como compromisso e honra para reforçar a imobilização da força de trabalho. Por exemplo, o "bom piaçabeiro" é aquele trabalhador extrativista que salda todas as suas dívidas, já o "mau piaçabeiro" é aquele que dá o "calote" no patrão, como apontado em Peres (2006) e Menezes (2020).

Tais discursos norteiam as relações extrativistas no rio Negro. Isso porque, para o piaçabeiro provar que é um bom trabalhador, ter uma alta produção e obter bens materiais (como casa e canoa), ele precisa desconstruir o estigma do "mau piaçabeiro". Ao fazer isso, entretanto, ele se envolve num jogo de subordinação e tem sua força de trabalho cada vez mais imobilizada.

Outra estratégia de enfrentamento nesse sistema de aviamento, acionada pelos piaçabeiros, é a venda de sua produção para outro comerciante que ofereceu vantagens, como preço mais alto nas fibras a serem compradas, deixando o comerciante que adiantou as mercadorias em prejuízo naquele momento. Esse fato acarreta, por um lado, o aumento da dívida anteriormente feita, por outro, este segundo piaçabeiro consegue resolver algum problema financeiro sem recorrer ao patrão ao qual está endividado, visto que é comum ao entregar as fibras extraídas, não obter saldo e, assim, continuar endividado.

A resistência também se manifesta quando esses trabalhadores extrativistas entregam sua produção encharcada de água, ou colocam areia ou galhos no interior do amontoado de fibras para que estas pesem mais, e assim consigam saldo que permita quitar as dívidas ou diminuí-las.

Quando esses trabalhadores acionam suas identidades étnicas, como tariano, tukano, baniwa, baré, arapaso, werequena, tuyuca e se organizam em unidades de mobilização, também estão enfrentando o sistema de aviamento, visto que começam a reivindicar direitos sociais, como a demarcação das suas terras, onde se localizam as unidades de produção, como o piaçabal e o castanhal.

Nesse sentido, em 2001 foi solicitada oficialmente a demarcação da "Terra Indígena do Baixo Rio Negro, Aracá e Padauiri" pelos indígenas associados da recém-criada Associação Indígena de Barcelos (Asiba). Os povos indígenas 
- como os Tariano, Tukano, Baniwa, Baré, Arapaso, Werequena, Tuyuca, dentre outros - que compõem essa unidade associativa querem assegurar suas práticas tradicionais e modos culturalmente distintos em seus territórios, que até então estavam sendo ameaçados pelos domínios dos patrões.

A área pretendida para demarcação corresponde às regiões de abrangência dos rios Caurés, Quiuini, Aracá, Demeni, Preto e Padauiri, nos municípios de Barcelos e Santa Isabel do Rio Negro (AM), na margem direita do rio Negro.

Em 2007 houve duas portarias da Funai instituindo dois grupos de trabalho para os estudos de identificação e delimitação das áreas indígenas; são elas: a portaria $\mathrm{n}^{\circ} 12$, de 12 de janeiro de 2007 e a portaria $\mathrm{n}^{\circ} 476$, de 29 de maio de 2007 (Fundação Nacional do Índio, 2007a, 2007b).

Peres (2010) aponta que os trabalhos realizados por essas duas equipes foram considerados insuficientes pela Coordenação Geral de Identificação e Delimitação (GCID) da Funai, portanto, as duas terras indígenas não foram demarcadas, e o movimento indígena no médio rio Negro continuou a reivindicar a demarcação de seus territórios.

Dois anos após a publicação das portarias acima mencionadas, a Funai instituiu novamente outra equipe técnica para a realização dos estudos de natureza antropológica. Entretanto, atualmente o processo iniciado pela portaria $\mathrm{n}^{\circ} 12$, de 12 de janeiro de 2007 (Fundação Nacional do Índio, 2007a) encontra-se "em identificação", sendo publicada recentemente a portaria $\mathrm{n}^{\circ} 1.032$, de $1^{\circ}$ de agosto de 2019 (Fundação Nacional do Índio, 2019), que designa grupo de trabalho para estudo fundiário e cartorial. Já o processo iniciado pela portaria $n^{\circ} 476$, de 29 de maio de 2007 (Fundação Nacional do Índio, 2007b) encontra-se com status de “declarada", conforme a portaria ${ }^{\circ}$ 783, de 6 de setembro de 2017 (Brasil, 2017).

Denunciar aos órgãos competentes também é uma estratégia de enfrentamento às situações de dominação que esse sistema impõe. Em 2011, na cidade de Barcelos, conheci o sr. Milton, da etnia baré e piaçabeiro que denunciou o patrão para o qual estava subordinado.

Ao trabalhar por três anos para esse comerciante, o sr. Milton nunca conseguiu saldar sua dívida. Durante seis meses esse trabalhador extrativista esforçou-se no piaçabal, juntamente com sua família, composta por esposa e 15 filhos. Economizando tudo o que podia e contando com a força de trabalho da família, o sr. Milton calculou que o resultado desses meses de trabalho ininterruptos seria suficiente para quitar a dívida e sair dessa relação com o 
patrão com saldo. O comerciante, entretanto, lhe apresentou uma dívida de R\$ 15.000,00 mesmo o sr. Milton afirmando que não devia mais; pelo contrário, existia um saldo de $\mathrm{R} \$ 500,00$ a ser recebido.

Após discussões, o sr. Milton, como indígena da etnia baré, recorreu à Associação Indígena de Barcelos que o incentivou a registrar um boletim de ocorrência e processar esse comerciante que estava o cobrando, e assim ele fez. No final, o sr. Milton recebeu o valor de $\mathbf{R} \$ 500,00$ que correspondia ao seu saldo e fora comprovado que ele não devia o valor de $\mathrm{R} \$ 15.000,00$ que o comerciante cobrava.

Esse episódio abriu precedentes para que outros piaçabeiros reivindicassem seus direitos trabalhistas e se associassem a alguma unidade de mobilização. Assim como a dívida começou a ser pensada como algo menos rígido, havia, portanto, a possibilidade do "calote", que vejo como um fenômeno que responde a séculos de exploração.

Em 2013 a Câmara Municipal de Barcelos e o Ministério Público Federal receberam denúncias dos piaçabeiros sobre a exploração do trabalhador nessa atividade, o que levou à judicialização desses conflitos sociais. A partir da instauração do inquérito civil em 2013, pelo Ministério Público Federal, para apurar denúncias sobre o trabalho análogo à escravidão no extrativismo da piaçaba, ocorreu uma operação conjunta entre o Ministério Público Federal (MPF/AM), Ministério Público do Trabalho (MPT), Ministério do Trabalho e Emprego (MTE) e Polícia Federal (PF), em maio de 2014.

Como resultado dessa operação, foram encontrados 13 piaçabeiros em condições consideradas degradantes e jornadas exaustivas. O comerciante nesse sistema de aviamento respondeu às acusações de redução à condição análoga a de escravo, conforme previsto no artigo 149 do Código Penal, de frustração de direito assegurado por lei trabalhista, constante do artigo 203 do mesmo código, e de falsificação de documento público, relativo ao artigo 297 do Código Penal.

Em janeiro de 2004, nove anos antes da operação do MPF e MPT, uma mulher da etnia baré encaminhou à Federação das Organizações Indígenas do Rio Negro (FOIRN) uma carta denunciando a situação de imobilização da força de trabalho de seu irmão e sua família nos piaçabais no igarapé do Maboabi, rio Preto, no município de Santa Isabel do Rio Negro. A denúncia dizia o seguinte:

[...] O indígena baré [...] e sua esposa Nair estão há 12 anos em mãos de patrão sem poder sair. Tem 5 filhos, sendo 3 meninas e 2 meninos, o mais velho 
tem 12 anos de idade. Ele é meu irmão, eles são meus sobrinhos. Quando ele quer sair o patrão diz que ele não pode porque ainda não pagou a conta. O meu irmão está sendo explorado, um paneiro de farinha chega a custar $\mathrm{R} \$ 70,00$. Assim ele vai ficando. Se ele não ficar com a farinha a este preço ele e seus filhos morrerão de fome. Portanto, eu estou comovida com situação do meu irmão. Por isso, solicito que esta instituição providencie a saída do mesmo daquele lugar e o mesmo possa trabalhar de forma justa e que seus filhos possam estudar. Após a saída o mesmo deverá morar comigo na cidade de Santa Isabel do Rio Negro. Em 11/01/2004. (Ministério Público Federal, 2013).

Ao receber essa carta, a FOIRN a encaminhou à FUNAI, que a encaminhou à promotora de Justiça no município de São Gabriel da Cachoeira, que por sua vez a enviou à Procuradoria Regional do Trabalho (PRT) da $11^{\mathrm{a}}$ Região. A partir daí, a PTR da $11^{\text {a }}$ Região começou a averiguar a procedência da denúncia e expediu em fevereiro daquele mesmo ano (2004) uma certidão que informava que essa denúncia não era um fato isolado, já que eram constantes tais relações no extrativismo da piaçaba no rio Negro e seus afluentes. Assim sendo, o MPT, por meio da PRT da $11^{\mathrm{a}}$ Região, formulou a representação n47/2004 (Ministério Público do Trabalho, 2013) e tomou providências junto à Polícia Federal e à Fiscalização do Trabalho em Brasília para realização conjunta de diligência.

Reivindicar e acionar as políticas de subvenção, tais como a PGPM-Bio, é uma forma de evidenciar a presença das práticas tradicionais do extrativismo, não de um modo puramente ambiental e econômico, mas, sobretudo, social. Isso reforça o enfrentamento ao aviamento, pois assevera a possibilidade de sair da dependência do patrão.

Desse modo, o piaçabeiro que vende o quilo da piaçaba a $\mathrm{R} \$ 1,40$ para 0 patrão pode requerer à Conab a subvenção de $\mathrm{R} \$$ 0,51, valor para chegar ao preço mínimo estipulado pelo Estado, que em 2016 correspondia a R\$ 1,91.

Os pagamentos no âmbito da PGPM-Bio começaram a ser pagos em Barcelos no ano de 2013. Segundo ofício do superintendente regional da Conab no Amazonas ao MPF, ${ }^{11}$ no ano de 2013 foram alcançados 86 trabalhadores extrativistas, sendo apresentadas 62,78 toneladas, totalizando um pagamento de $\mathrm{R} \$ 24.465,12$.

11 Documento extraído do inquérito civil público 1.13.000.002364/2013-43. 
Em 2014 o número chegou a 37 piaçabeiros, sendo 121,667 toneladas com um pagamento de $\mathrm{R} \$ 47.331,70$. E em 2015 foram pagos $\mathrm{R} \$$ 8.665,90 a 18 piaçabeiros por 43,18 toneladas.

A partir de entrevistas em Barcelos com a gerente local do Idam, pude registrar que em 2016 foram subvencionados 295,30 toneladas e até o início de 2017 já tinham 130 toneladas aguardando pagamento, tendo recurso para entrar nessa política naquele ano para até 260 toneladas, que somariam $\mathrm{R} \$ 193.528,30$.

Quando os trabalhadores extrativistas acionam suas identidades étnicas como recurso ao enfrentamento da imobilização pela dívida estão reivindicando direitos conquistados historicamente mediante um processo organizativo e lutas políticas.

Desse modo, participar de unidades de mobilização, tais como associações e cooperativas, também compõe esse cenário de enfrentamento, mesmo que de forma silenciosa. Isso porque as unidades de mobilização foram as que receberam as denúncias dos agentes sociais e as levaram aos órgãos competentes. Além do que é nos espaços dessas unidades que acontecem as discussões e mobilizações das demandas de seus membros.

A partir dos efeitos sociais do processo de judicialização, tem-se visto uma força mobilizadora e uma consciência política para enfrentar séculos de imobilização da força de trabalho e a dívida nos piaçabais, não de forma abrupta, mas através de um processo de resistência e enfrentamento, que pode ser uma resposta ao enfraquecimento do sistema de aviamento.

\section{Referências}

ALMEIDA, W. B. de. Terras tradicionalmente ocupadas: terra de quilombo, terras indígenas, "babaçuais livres", "castanhais do povo". Manaus: PPGSCA-UFAM, 2006.

ALMEIDA, W. B. de. Biologismos, geografismos e dualismos: notas para uma leitura crítica de esquemas interpretativos da Amazônia que dominam a vida intelectual. In: ALMEIDA, W. B. de. Antropologia dos archivos da Amazônia. Rio de Janeiro: Casa 8: Fundação Universidade do Amazonas, 2008. p. 15-126.

AVÉ-LALLEMANT, R. No rio Amazonas (1859). Belo Horizonte: Itatiaia; São Paulo: Ed. da Universidade de São Paulo, 1980. 
BENCHIMOL, S. Estrutura geo-social e econômica da Amazônia. Manaus: Edições Governo do Estado do Amazonas, 1966.

BRASIL. Lei $n^{\circ}$ 1.806, de 6 de janeiro de 1953. Dispõe sôbre o Plano de Valorização Econômica da Amazônia, cria a Superintendência da sua execução e dá outras providências. Rio de Janeiro, 1953. Disponível em: http://www.planalto.gov.br/ccivil_03/ leis/1950-1969/L1806.htm. Acesso em: 25 set. 2019.

BRASIL. Ministério do Meio Ambiente. Portaria interministerial $n^{\circ} 380$, de 11 de dezembro de 2015. Institui o Plano Nacional para o Fortalecimento das Comunidades Extrativistas e Ribeirinhas-PLANAFE e dá outras providências. Diário Oficial da União, Brasília, 16 dez. 2015. Seção 1, p. 109.

BRASIL. Ministério da Justiça e Segurança Pública. Portaria $n^{\circ} 783$, de 6 de setembro de 2017. Diário Oficial da União, Brasília, 11 set. 2017. Seção 1, p. 22. Disponível em: https://www.in.gov.br/web/dou/-/portaria-n-783-de-6-de-setembro-de-2017-19282575. Acesso em: 25 set. 2019.

CARDOSO, F. H.; MÜLLER, G. Amazônia: expansão do capitalismo. São Paulo: Brasiliense, 1978.

CARVALHO JÚNIOR, A. D. Tapuia - A invenção do índio da Amazônia nos relatos de viagem filosófica (1783-1792). In: CARVALHO JÚNIOR, A. D.; NORONHA, N. M. de. (org.). A Amazônia dos viajantes: história e ciência. Manaus: Editora da Universidade Federal do Amazonas, 2011. p. 40-128.

CHAMBOULEYRON, R.; BOMBARDI, F. A. Descimentos privados de índios na Amazônia colonial (séculos XVII e XVIII). Varia Historia, Belo Horizonte, v. 27, n. 46, p. 601623, jul./dez. 2011.

COSTA, F. Carta pastoral de Frederico Costa - bispo do Amazonas. Fortaleza: Typ. Minerva, 1909.

CUNHA, E. da. Um paraíso perdido. Manaus: Valer: Governo do Estado do Amazonas: Editora da Universidade Federal do Amazonas, 2003.

DIAS, A. G. Correspondência ativa de Antônio Gonçalves Dias (1840-1864). Anais da Biblioteca Nacional, v. 84, p. 208-308, 1964.

ESTERCI, N. Imobilização por dívida e formas de dominação no Brasil de hoje. Lusotopie, n. 3, p. 123-137, 1996.

FERREIRA, A. R. Viagem filosófica ao Rio Negro. Manaus: Editora da Universidade Federal do Amazonas, 2007. 
FUNDAÇÃO NACIONAL DO ÍNDIO. Portaria $\mathrm{n}^{\circ}$ 12, de 12 de janeiro de 2007. Diário Oficial da União, Brasília, 19 jan. 2007a. Seção 2, p. 22. Disponível em: https://www. in.gov.br/web/dou/-/portaria-n-12-de-12-de-janeiro-de-2007-180849913. Acesso em: 25 set. 2019.

FUNDAÇÃO NACIONAL DO ÍNDIO. Portaria n 476, de 29 de maio de 2007. Diário Oficial da União, Brasília, 4 jun. 2007b. Seção 2, p. 22. Disponível em: https://www. in.gov.br/web/dou/-/portaria-n-476-de-29-de-maio-de-2007-181361712. Acesso em: 25 set. 2019.

FUNDAÇÃO NACIONAL DO ÍNDIO. Portaria $n^{\circ} 1.032$, de $1^{\circ}$ de agosto de 2019. Diário Oficial da União, Brasília, 2 ago. 2019. Seção 2, p. 51. Disponível em: https://www. in.gov.br/web/dou/-/portaria-n-1.032-de-1-de-agosto-de-2019-208549963. Acesso em: 25 set. 2019.

JOBIM, A. Três municípios amazonenses. Manaus: Edições Governo do Estado do Amazonas, 1965.

KOCH-GRÜNBERG, T. Dois anos entre os indigenas: viagem ao noroeste do Brasil (1903-1905). Manaus: EDUA: FSDB, 2005.

LOUREIRO, A. J. S. O Amazonas na época imperial. Manaus: Valer, 2007.

MEIRA, M. O tempo dos patrões: extrativismo da piaçava entre os índios do Rio Xié (alto Rio Negro). 1993. Dissertação (Mestrado em Antropologia Social) - Instituto de Filosofia e Ciências Humanas, Universidade Estadual de Campinas, Campinas, 1993.

MENEZES, E. S. de. Trabalho análogo à escravidão nos piaçabais em Barcelos - Amazonas: entre a "honra" e a "judicialização". In: EILBAUM, L.; SCHUCH, P.; CHAGAS, G. F. (org.). Antropologia e direitos humanos: volume 8. Rio de Janeiro: E-papers, 2020. p. 13-47.

MINISTÉRIO PÚBLICO DO TRABALHO. Processo de representação nº 47/2004 sobre trabalho escravo. In: MINISTÉRIO PÚBLICO FEDERAL. Procuradoria da República no Estado do Amazonas. $5^{\circ}$ Ofício. Inquérito civil $n^{\circ} 1.13 .000 .002364 / 2013-$ 43. Volume I a VII. Manaus, 2013. v. 2, p. 2.

MINISTÉRIO PÚBLICO FEDERAL. Procuradoria da República no Estado do Amazonas. $5^{\circ}$ Ofício. Inquérito civil $n^{\circ}$ 1.13.000.002364/2013-43. Volume I a VII. Manaus, 2013.

SANTA-ANNA NERY, F. J. de [Barão de Santa-Anna Nery]. O país das Amazonas. Belo Horizonte: Itatiaia; São Paulo: Ed. da Universidade de São Paulo, 1979.

NIMUENDAJÚ, C. Excursões pela Amazônia. Revista de Antropologia, São Paulo, v. 44, n. 1, p. 189-200, 2001. 
PACHECO DE OLIVEIRA, J. O caboclo e o brabo: notas sobre duas modalidades de força de trabalho na expansão da fronteira amazônica do século XIX. In: SILVEIRA, E. (org.). Encontros com a civilização brasileira. Rio de Janeiro: Civilização Brasileira, 1979. p. 101-140.

PACHECO DE OLIVEIRA, J. Elementos para uma sociologia dos viajantes. In: PACHECO DE OLIVEIRA, J. (org.). Sociedades indígenas e indigenismo no Brasil. Rio de Janeiro: UFRJ, 1987. p. 84-148.

PERES, S. A economia moral do extrativismo no Médio Rio Negro: aviamento, alteridade e relações interétnicas na Amazônia. Antropolítica: Revista Contemporânea de Antropologia e Ciência Política, Niterói, n. 21, p. 151-170, 2. sem. 2006.

PERES, S. Associativismo, etnicidade indígena e transformações sociais: a manufatura política de direitos territoriais em Barcelos. In: ALMEIDA, A. W. B. de; FARIAS JÚNIOR, E. de A. F. (org.). Mobilizações étnicas e transformações sociais no rio Negro. Manaus: UEA Edições, 2010. p. 213-232.

REIS, A. C. F. O processo histórico da economia amazonense. Rio de Janeiro: Imprensa Nacional, 1944.

REIS, A. C. F. Preâmbulo. In: BENCHIMOL, S. O Banco do Brasil na economia do Amazonas. Rio de Janeiro: SPVEA, 1958. p. 1-16. (Coleção Araújo Lima).

REIS, A. C. F. Entrechoque. Revista do Instituto Geográfico e Histórico do Amazonas, v. 9, n. 1, p. 4, 1977.

SPIX, J. B. von; MARTIUS, C. F. P. von. Viagem pelo Brasil: 1817-1820: Spix e Martius: vol. 3. Belo Horizonte: Itatiaia, 1981.

SUPERINTENDÊNCIA DO PLANO DE VALORIZAÇÃO ECONÔMICA DA AMAZÔNIA. Perspectiva do primeiro plano quinquenal e concepção preliminar da valorização econômica da Amazônia. Belém, 1954.

TEIXEIRA, C. C. Servidão humana na selva: o aviamento e o barracão nos seringais da Amazônia. Manaus: Valer: EDUA, 2009.

WALLACE, A. R. Viagens pelos rios Amazonas e Negro. São Paulo: Companhia Editora Nacional, 1953.

Recebido: 30/09/2019 Aceito: 27/04/2020 | Received: 9/30/2019 Accepted: 4/27/2020 